\title{
Knowledge, Attitude and Practice of Mothers Toward Immunization of Their Infants in Shashemene Referral Hospital, West Arsi Zone, Oromia Regional State, Ethiopia
}

\author{
Yonas Gurmu*, Gada Edea, Eniyewu Molla, Dirriba Tari, Elifitu Lamesa, Elsa Belay \\ Department of Nursing, College of Medicine \& Health Sciences, Ambo University, Ambo, Ethiopia \\ Email address: \\ yonasgurmu@gmail.com (Y. Gurmu) \\ ${ }^{*}$ Corresponding author \\ To cite this article: \\ Yonas Gurmu, Gada Edea, Eniyewu Molla, Dirriba Tari, Elifitu Lamesa, Elsa Belay. Knowledge, Attitude and Practice of Mothers Toward \\ Immunization of Their Infants in Shashemene Referral Hospital, West Arsi Zone, Oromia Regional State, Ethiopia. American Journal of \\ Biomedical and Life Sciences. Vol. 9, No. 2, 2021, pp. 111-119. doi: 10.11648/j.ajbls.20210902.12
}

Received: February 21, 2021; Accepted: April 16, 2021; Published: April 29, 2021

\begin{abstract}
Background: Ethiopian was able to expand the immunization service by introducing new vaccines into the country routine immunization program that increased the number of antigens from 10 to 12. Expanded Program on Immunization (EPI) is one of the key programs in World Health Organization (WHO) Ethiopia under the Maternal, Child Health and Nutrition (MCHN). Compliance to vaccination may be influenced by understanding of the community towards the service. Objective: To assess the knowledge, Attitude and practice of mothers towards vaccination of their infants in Shashemene referral Hospital west Arsi, Zone Oromia Regional state, South-Ethiopia, 2018. Method: Institutional based cross-sectional study design was conducted in shashemene Referral Hospital from February to April 10, 2018. Face to face structured Interview questionnaire was used by systematic sampling techniques. Data collection was start from March 01 to 30, 2018 G. C and after reviewing, data was analyzing with SPSS software version 20. Result: A total of 228 mothers were participated on this study, giving the response rate of $98.1 \%$. From the total respondents $(52.3 \%)$ of mothers have good knowledge and $(42.3 \%)$ of them had good practices of services utilization of vaccination for their infants. Conclusion: This study showed that $52.3 \%, 67.7 \%, 42.3 \%$ of study participant had good knowledge, attitude, and practice towards immunization of infants respectively. Educational interventions are required to improve parents' knowledge, attitude, and practice.
\end{abstract}

Keywords: Knowledge, Attitude, Practice, Immunization, Shashemene, Mothers

\section{Introduction}

It is undeniable that vaccines have been an important part in preventive medicine based on their successes in controlling vaccine-preventable diseases in the developed world [1].

World Health Organization (WHO) estimated that annually up to three million children's lives are saved by vaccinations, but still another three million lives worldwide are lost from vaccine-preventable diseases. In 2009, WHO estimated that if global vaccine coverage increased to $90 \%$ by 2015 , then approximately two million deaths of children under the age of five would be prevented [2].

Ten years later, in 1984, the WHO established a standardized vaccination schedule for the original EPI vaccines: Bacillus Calmette-Guerin (BCG), diphtheria-tetanus-pertussis (DTP), oral polio, and measles [3]. During the inception of Expanded
Program on Immunization the objective was to increase immunization coverage by $10 \%$ annually and reach $100 \%$ in 10 years but this target has not been realized even after two decades. The target group when the program started were children under two years of age until it changed to less than one year in 1986 to be in line with the global immunization target [4].

Ethiopia compressive multiyear plan 2011-2012. The EPI aims at delivering the primary immunization series to at least $90 \%$ infant. Maternal and child health are among the Ethiopia government priority health programs and efforts are being implemented to reduce maternal and child mortality [5].

In 2014, the Ministry of Health (MOH), in partnership with UNICEF, and other bilateral agencies, has intensified efforts to improve routine immunization at peripheral levels. Despite visible gains that have been recorded in the EPI program, the 2012 national Immunization coverage survey showed a lower 
than reported coverage with wide regional variation and problems of drop outs. Not only this, but olso knowledge, and practice of mother toward immunization is great role to eradicate the left $40 \%$ of unimmunized child and predisposing factor of missed opportunity of immunization [6].

All over the world vaccine preventable diseases still account for about 2 million death per year measles is the major killer of children accounting for 4,55000 deaths every year, despite a $48 \%$ reduction over the past six year, with most of those death occurring in the developing country. World Health Organiztion estimates $29 \%$ of death among children 1-59 month of age is vaccine preventable. Due to this WHO has estimated that if all the vaccines now available against childhood diseases were widely adopted, and if countries could raise vaccine coverage to a global average of $90 \%$, by 2015 an additional two million deaths a year could be prevented among children under five years old [7]. According to EDHS 2016 Infants and under five children mortality rate has been a steady decline over the last 16 years [8, 9].

It is directed in the implementation guideline to introduce Inactivated Polio Virus (IPV), measles-rubella, meningitis, and yellow fever vaccines for less than one-year-old children [10].

Despite the fact that the government of Ethiopia has increased its efforts to enhance good immunization practices, however, vaccine preventable disease are still now one of the main health problems facing children in under-five age group and from 67 deaths per 1,000 live births majority of child death due to vaccine preventable disease in Ethiopia [11].

To fill those gaps, this study was assess the knowledge, attitude and practices of mother to ward immunization of their infants.

\section{Method}

Study was conducted at Shashemene referral Hospital. Shashemene referral Hospital is found in Shashemene warada (Kuyera town) it's situated $238 \mathrm{~km}$ away from Addis Ababa and $7 \mathrm{~km}$ from Shashemene town in west Arsi zone of Oromia regional state, Ethiopia. The study was conducted from February to April 10, 2018. Institutional based cross-sectional study was conducted. All mothers who have less than or equal to one year infant who attended shashemene referral Hospital for immunization of their infants and give consents are included. Mothers who are unable to speak /hear are excluded.

Sample size was determined by the following formula using proportion of knowledge 55\%, 95\% CI. from previous research done at Addis Ababa Health center.

$$
\mathrm{n}=\frac{(z \alpha / 2)^{2} \times p(1-p)}{d^{2}}
$$

$$
\begin{aligned}
& \mathrm{n}=[1.96]^{2} \times[0.55] \times[0.45] /[0.05] 2 \\
& =380
\end{aligned}
$$

The above sample was going to be taken from a relatively small population $(<10,000)$, then the sample size has been adjusted as;

$$
\mathrm{n}=\mathrm{n}_{0} /\left(1+\mathrm{n}_{0} / \mathrm{N}\right)
$$

$$
\begin{aligned}
& =380 / 1+(380 / 450) \\
& =207
\end{aligned}
$$

Then we take $10 \%$ of 207 as a contingency value as nonresponse during interview. Finally a total number of sample size of the study is 228

Where, $\mathrm{n}=$ desired sample

$z=$ level of significance at $95 \%$ confidence interval

$\mathrm{p}=$ an estimate of the proportion of mother attending immunization for their infant in one month '

$\mathrm{d}=$ marginal error

$\mathrm{N}=$ total sample

\subsection{Sampling Technique}

Systematic sampling technique to select the study population. K-value equal to $2(\mathrm{k}=450 / 228=2)$. Every other mother was selected as a sample size. All mothers were come for immunization services at EPI unit for their under one year child selected as sample, until sample size was reached.

A total number of sample size of the study is 228 . The structured questionnaire that measures the sociodemographic characteristics, knowledge, Attitude and practice of mothers towards immunization was used to collect the data. The structured questionnaire was adopted from English version after reviews of different literatures, Then it translates in to Afan Oromo and Amharic version in order to simplify the data collection procedure, and back to English, to check its consistency. Data was collected by nurse face to face interview using structured questionnaire.

\subsection{Operational Definition}

Good:-Those mothers who answer correctly the knowledge, Attitude, practice questions and if they score the mean value and above.

Poor:-Those mothers who answer correctly the knowledge, Attitude, practice questions and if they score below the mean value.

Data was collected by using pretested structured questionnaire by principal investigator. The questionnaire was further modified after a pre-test was conducted. The pre-test was done in out of the study area at Melka oda Hospital before started data collection The data was checked for the completeness, accuracy, and consistency at the end of every day. The data was checked for completeness, coded and entered then analyzed use statistical package for social science (SPSS) vervion 20.

Ethical clearance was obtained from the Ethical Review committee of Ambo University, College of Medicine and Health Science department of Nursing. Then verbal informed consent was obtain from responsible bodies in the Shashemene referral Hospital prior to data collection and after the purpose of the study was explained. Participant confidentiality was kept during interviews.

\section{Result}

Out of 228 respondents of had given a response to our questionnaire which accounts a response rate of $98.7 \%$. Out 
of this $50.4 \%$ of respondents were young women $(21-26$ years). From the total of mothers participated, $36.3 \%$ were learned from grade 9-12. Majority of the mothers were married (98.7). From all mothers 54.4\% were Muslim and $77.4 \%$ of them were house wife, $35.8 \%$ children were above two months. More than half of the respondent (56.6\%) has average monthly income of greater than 1000 ETB.
About $42.3 \%$ of mothers were always bringing their infants for immunization according to the schedule given by health professionals (Table 4).

The level of education of mothers was observed to be very significant $(p=0.003)$ to their knowledge on immunization. The higher the level of education of the mother, the greater their knowledge on immunization.

Table 1. Socio demographic and related characteristics in shashemene referral Hospital, ( $n=226)$.

\begin{tabular}{|c|c|c|c|}
\hline Characteristics & & Frequency & Percent (\%) \\
\hline \multirow{4}{*}{ Age of mother in (years) } & $15-20$ years & 47 & 20.8 \\
\hline & $21-25$ yeas & 114 & 50.4 \\
\hline & $26-30$ years & 47 & 20.8 \\
\hline & $>31$ years & 12 & 5.3 \\
\hline \multirow{5}{*}{ Educational status of mother } & unable to read and write & 28 & 12.4 \\
\hline & able to read and write & 13 & 5.8 \\
\hline & grade $1-4$ & 12 & 5.8 \\
\hline & grade $5-8$ & 57 & 25.2 \\
\hline & grade $9-12$ & 82 & 36.3 \\
\hline \multirow{4}{*}{ Religions } & Muslim & 123 & 54.4 \\
\hline & Orthodox & 51 & 22.6 \\
\hline & Protestant & 47 & 20.8 \\
\hline & Others & 5 & 2.2 \\
\hline \multirow{3}{*}{ Marital status of mothers } & Married & 223 & 98.7 \\
\hline & Divorced & 2 & 0.9 \\
\hline & Widowed & 1 & 0.4 \\
\hline \multirow{3}{*}{ Occupation of mothers } & House wife & 175 & 77.4 \\
\hline & Merchants & 23 & 10.2 \\
\hline & Gov employed & 28 & 12.4 \\
\hline \multirow{4}{*}{ House monthly income ETB } & $<500$ & 9 & 4 \\
\hline & $500-1000$ & 55 & 24.5 \\
\hline & $1000-5000$ & 128 & 85 \\
\hline & $>5000$ & 34 & 15 \\
\hline \multirow{4}{*}{ Ethnicity } & Oromo & 193 & 85.4 \\
\hline & Amhara & 23 & 10.2 \\
\hline & Tigray & 2 & 0.9 \\
\hline & Others & 8 & 3.5 \\
\hline \multirow{3}{*}{ Place of birth infants } & At home & 122 & 54 \\
\hline & At health institution & 104 & 46 \\
\hline & $0-10$ week & 69 & 30.5 \\
\hline \multirow[t]{2}{*}{ Age of infants } & 11-14 week & 81 & 35.8 \\
\hline & 15 week-1 years & 76 & 33.6 \\
\hline
\end{tabular}

Knowledge of Respondents on Infant Vaccination and Vaccine Preventable Diseases

Of 226 respondents, $223(98,7)$ have ever heard information about vaccination (Table 2).

Table 2. Knowledge of mothers regarding infants' vaccination in shashemene referral hospital 2018.

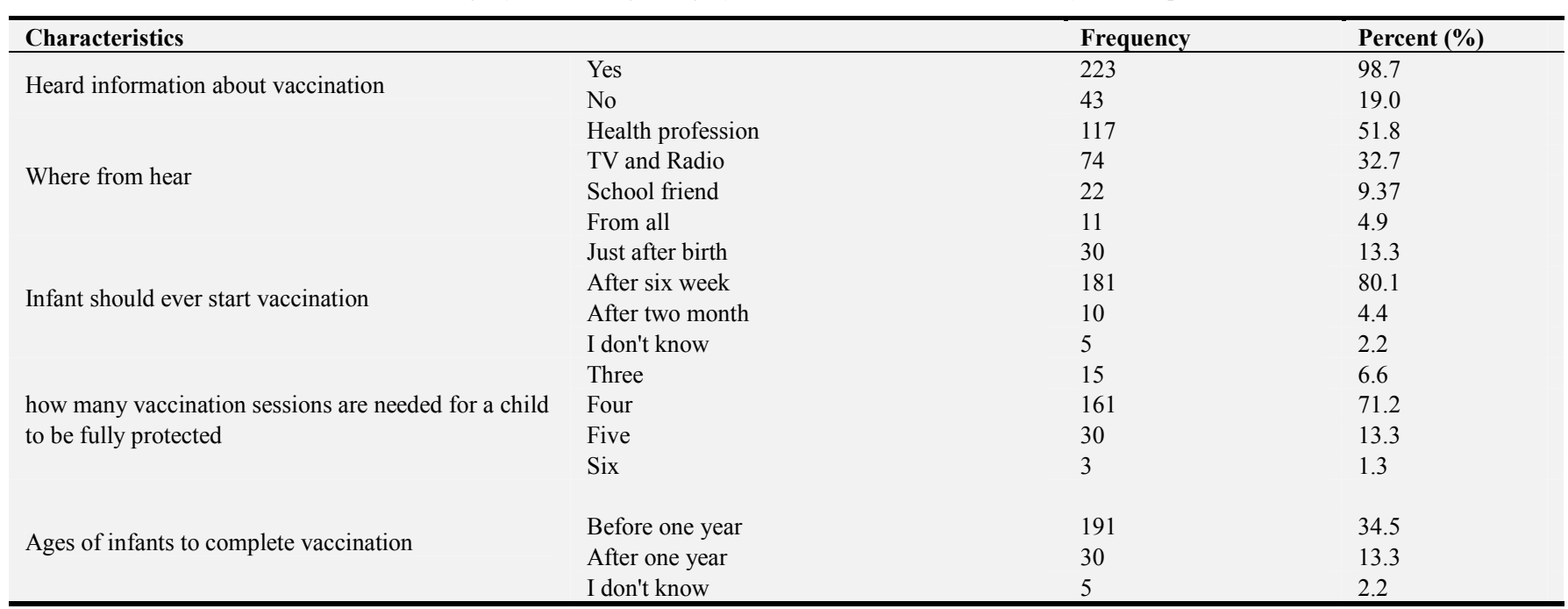




\begin{tabular}{llll}
\hline Characteristics & & Frequency & Percent (\%) \\
\hline & Measles tetanus TB pneumonia, dept, pertusis & 208 & 92.0 \\
Name of vaccine preventable disease & Only tetanus and measles & 30 & 13 \\
& Only TB and pneumonia & 13 & 5.8 \\
& I don't know & 2 & 0.9 \\
Number of vaccine preventable disease & More than two disease & 203 & 89.8 \\
& Single disease & 3 & 0.13 \\
& I don't know & 20 & 8.8 \\
\hline
\end{tabular}

Attitude of Respondents To wards Immunization

This study $67.7 \%$ of mothers had a favorable attitude towards immunization of their infants, summarized on (table 3 )

Table 3. Attitude of mothers towards infants' immunization in Shashemene referral Hospital.

\begin{tabular}{|c|c|c|c|}
\hline Characteristics & & frequency & Percent (\%) \\
\hline Favourable opinion & & 154 & 68.1 \\
\hline \multirow[t]{2}{*}{ Unfavourable opinion } & & 72 & 31.9 \\
\hline & Agree & 117 & 51.8 \\
\hline \multirow[t]{3}{*}{ EPI program is being free } & Disagree & 99 & 43.8 \\
\hline & Don't know & 10 & 4.4 \\
\hline & Agree & 223 & 98.7 \\
\hline \multirow[t]{2}{*}{ Immunization is preventable disease } & Disagree & 1 & 0.1 \\
\hline & Agree & 13 & 5.8 \\
\hline \multirow[t]{3}{*}{ Vaccination side effects are dangerous } & Disagree & 210 & 92.9 \\
\hline & Don't know & 3 & 1.3 \\
\hline & Agree & 48 & 21.2 \\
\hline \multirow[t]{3}{*}{ Vaccinators do experiment on infant } & Disagree & 157 & 69.5 \\
\hline & Don't know & 21 & 9.3 \\
\hline & Agree & 27 & 11.9 \\
\hline \multirow[t]{2}{*}{ Vaccination makes infant sick } & Disagree & 198 & 87.6 \\
\hline & Agree & 178 & 78.8 \\
\hline \multirow[t]{3}{*}{ Positive attitude of mother toward immunization } & Disagree & 47 & 20.8 \\
\hline & Don't know & 1 & 0.4 \\
\hline & Agree & 10 & 4.4 \\
\hline \multirow[t]{2}{*}{ Immunization is important for only none serious disease } & Disagree & 172 & 76.1 \\
\hline & Don't know & 44 & 19.5 \\
\hline
\end{tabular}

Table 4. Practice of respondent mothers regarding immunization of infants in shashemene referral Hospital 2018.

\begin{tabular}{|c|c|c|c|}
\hline Characteristics & & Frequency & Percent $(\%)$ \\
\hline \multirow{2}{*}{ Adhering immunization schedule } & Yes & 216 & 95.6 \\
\hline & No & 12 & 4.4 \\
\hline \multirow{2}{*}{ Confirming BCG scar of vaccination } & Yes & 189 & 83.6 \\
\hline & No & 37 & 16.4 \\
\hline \multirow{2}{*}{ Availability of EPI card During immunization } & Yes & 222 & 98.2 \\
\hline & No & 4 & 1.8 \\
\hline Infant immunization practices always by EPI card & Yes & 226 & 100 \\
\hline
\end{tabular}

Majority of mothers $217(96 \%)$ where taken TT More than half of mothers 121 (53.5) where take above two Vaccination during pregnancy.

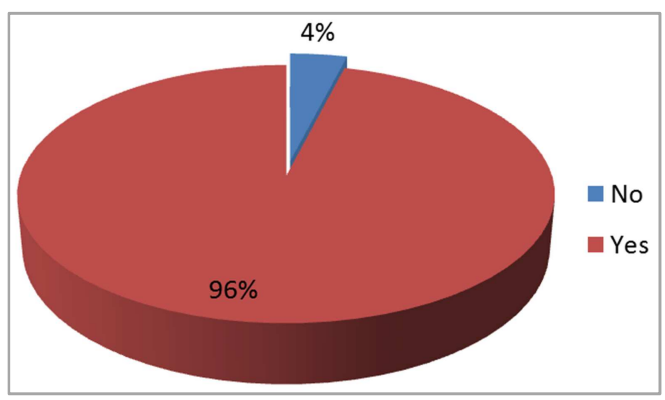

Figure 1. Tetanus toxoid (TT) vaccination of mothers at shashemene referral Hospital, in 2018.
TT vaccination.

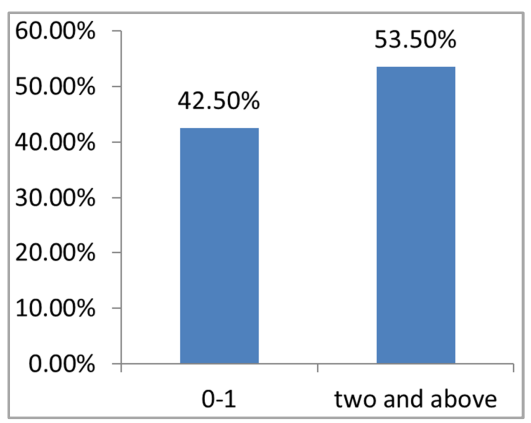

Figure 2. Number of TT vaccine had taken by mothers at shashemene referral Hospital in 2018. 
Table 5. Factors associated with respondent mothers' Practice regarding immunization of infants in shashemene referral hospital 2018.

\begin{tabular}{|c|c|c|c|c|}
\hline \multirow{2}{*}{ Variables } & \multicolumn{2}{|c|}{ Practices No (\%) } & \multirow{2}{*}{$\operatorname{COR}(95 \% \mathrm{CI})$} & \multirow{2}{*}{$\operatorname{AOR}(95 \% C I)$} \\
\hline & Poor practices & Good practices & & \\
\hline Mother education illiterates & $21(75)$ & $7(25)$ & 1 & 1 \\
\hline Able to read and write & $10(76.9)$ & $3(23.1)$ & $0.9(0.191,4.232)$ & $0.878(0.173,4.457)$ \\
\hline Grade 1-4 & $10(83.3)$ & $2(16.7)$ & $0.6(0.105,3.427)$ & $0.665(0.111,4.022)$ \\
\hline Grade $5-8$ & $28(49.1)$ & $29(50.9)$ & $3.107(1.142,8.452)$ & $3.179(1.116,9.056)$ \\
\hline Grade 9-12 & $49(59.8)$ & $33(50.2)$ & $2.02(0.772,5.290)$ & $2.44(0.818,6.134)$ \\
\hline University/college & $12(35.3)$ & $22(64.7)$ & $5.500(1.817,16.646)$ & $8.837(2.679,29.150)$ \\
\hline Deliver at home & $37(67.3$ & $18(32.7$ & 1 & 1 \\
\hline \multicolumn{5}{|l|}{ Age of infant } \\
\hline $0-10$ weeks & $53(76.8)$ & $16(23.2)$ & 1 & 1 \\
\hline $11-14$ weeks & $45(55.6)$ & $36(44.4)$ & $2.650(1.302,5.392)$ & $3.411(1.509,7.714)$ \\
\hline 15 weeks- 1 years & $32(42.1)$ & $44(57.9)$ & $4.555(2.215,9.367)$ & $6.805(2.875,16.106)$ \\
\hline \multicolumn{5}{|l|}{ Occupation of mother } \\
\hline House wife and farmer & $107(61.1)$ & $68(38.9)$ & 1 & 1 \\
\hline Merchant & $14(60.9)$ & $9(39.1)$ & $1.012(0.415,2.465)$ & \\
\hline Government employee & $9(32.1)$ & $19(67.9)$ & $3.322(1.421,7.767)$ & \\
\hline
\end{tabular}

\section{Discussion}

Immunization is an important public health interventions strategy to reduce the morbidity and mortality associated with infectious diseases. Vaccine preventable diseases remain the most common cause of childhood mortality with an estimated two million deaths each year [1,7]. Uptake of vaccination services is dependent not only on provision of these services but also on other factors including knowledge, attitude and factor affects practices of mothers vaccine utilization.

In this study, $223(98.7 \%)$ of mothers have heard information about infant immunization, and 117 (51.8\%) of them have accesses of information from health professionals. Similarly study done Saudi Arabia 2017 Most of them $(58.1 \%)$ had their information regarding child vaccination from medical staff, followed by social media $(17.4 \%)[1,3]$.

In this study $153(67.7)$ of mother had a positive attitude towards vaccination and $68.1 \%$ of them had friendly seen the health personnel. Despite the fact that respondents had positive attitude towards the EPI program and vaccine providers in general, a large proportion $31.9 \%$ of mothers believed that vaccines are given for infants to prevent non serious diseases [12]. This indicate that respondents have inadequate knowledge of related to vaccine preventable disease, indirectly affected their attitude.

Regarding immunization practice, those mothers who had infants with the age range of week, a 11-14 weeks three times $3.41195 \%$ CI: $(1.509,7.714)$ and 9-12 month were six times $6.80595 \%$ CI: $(2.875,16.106)$ significantly associated with mothers' immunization practices than those mothers who had infants 0-10 week old.

Similarly study done at Addis Ababa health center those mothers who had infants with the age range of 1-2 months, 23 months and 9- 12 months were four times significantly associated with mothers' immunization practices than those mothers who had infants aged 0-1 month old infants' immunization practice than their counter parts, respectively [19]. This show that where mothers' more contact with health personal for immunization services they got knowledge, and more practice of child vaccination.

In this study $13.3 \%$ of respondents correctly mentioned the time when infants should begin BCG vaccination (just after birth) and study Addis Ababa show that $90 \%$ of infants should start BCG vaccination just after birth.

Literate respondents who attend elementary school were about three times $[\mathrm{AOR}=3.179$ 95\%CI: $(1.116,9.056)$ whereas mother there who achieved higher education nine times $[\mathrm{AOR}=8.83795 \% \mathrm{CI}:(2.679,29.150)$ had infants immunization practices than unable to read and write respondents. similarly institutional based study at Arbaminch revealed Children from educated mothers had better chance to be fully immunized than children from not educated mother AOR (95\%CI $2.22(1.31,3.76)$ [20].

This revealed an association between higher paternal educational level and higher knowledge and attitude towards child immunization practices.

This paper has its own strength because it is based on primary data and can be used as base-line information for intervention programs and further investigation. It was institution based study and the number of mothers having unfavorable attitude could be decreased.

\section{Conclusion}

This study showed that $52.3 \%, 67.7 \%, 42.3 \%$ of study participant had good knowledge, attitude, and practice towards immunization of infants respectively. Educational interventions are required to improve parents' knowledge, attitude, and practice.

\section{Abbreviations}

$\begin{array}{ll}\text { AU } & \text { Ambo University } \\ \text { DPT } & \text { Diphtheria, pertussis tetanus } \\ \text { EDHS } & \text { Ethiopian demographic health survey } \\ \text { EPI } & \text { Expanded program of immunization } \\ \text { Epi } & \text { Epidemiological information } \\ \text { HepB } & \text { Hepatitis B virus } \\ \text { HEW } & \text { Health extension workers }\end{array}$




$\begin{array}{ll}\text { Hib } & \text { Homophiles influenza B type } \\ \text { KP } & \text { Knowledge, Practice } \\ \text { MDG } & \text { Millennium Development Goal } \\ \text { MDVP } & \text { Multi dose open policy } \\ \text { OPV } & \text { Oral polio vaccine } \\ \text { PCV } & \text { Pneumococcal vaccine } \\ \text { SPSS } & \text { Statistical package for the social science } \\ \text { TT } & \text { Tetanus toxoid } \\ \text { WHO } & \text { World Health Organization }\end{array}$

\section{Declarations}

\section{Ethics Approval and Consent to Participate}

The research project was reviewed by an Institutional Review Board of Ambo University. Permission to conduct the research was obtained from the authorities in the study settings and written informed consents were secured from each participant. The age of participants were greater than or equal to 18 years old.

\section{Consent for Publication}

Not applicable

\section{Availability of Data and Materials}

Datasets used and /or analyzed during the current study available from the corresponding author on reasonable request.

\section{Competing Interests}

The authors declare that they have no competing interests.

\section{Funding}

The study was funded by Ambo University. This funding source had role in the design of this study and have role during its execution, analyses, interpretation of the data.

\section{Authors' Contributions}

YG, GE, EM, DT, EL, and EB were participated from the inception of the research idea to proposal development, data collection, analysis and preparation \& revision of the manuscript for publication. The authors read and approved the final version of the manuscript.

\section{Acknowledgements}

We are grateful to Ambo University, College of Medicine and Health Science for all their priceless supports. Finally we would like to thank supervisors, data collectors and all study participants.

\section{Appendix}

\section{Questionnaire}

Questionnaire prepared to collect data for the assessment of knowledge, attitude and practice of mothers towards immunization, in shashemene referral Hospital west Arsi, zone Oromia Region, Ethiopia, 2018

Participant Identification Number: Date:

Section A: Socio-demographic characteristic related questions

\begin{tabular}{|c|c|c|}
\hline$\overline{\text { S. No. }}$ & Questions & Responses \\
\hline \multirow[t]{2}{*}{101} & What is your age? & \\
\hline & & Married \\
\hline \multirow[t]{3}{*}{102} & Mother's marital status? & Divorced \\
\hline & & Widowed \\
\hline & & $\begin{array}{l}\text { unable to read and write } \\
\text { able to read and write }\end{array}$ \\
\hline \multirow{5}{*}{103} & Mothers educational status? & Grade 1-4 \\
\hline & Mothers educational status? & Grade 5-8 \\
\hline & & Grade $9-12$ \\
\hline & & College/University \\
\hline & & A. Orthodox \\
\hline \multirow{4}{*}{104} & Religion & Muslim \\
\hline & & Protestant \\
\hline & & Other, specify \\
\hline & & House wife \\
\hline \multirow{3}{*}{105} & What is occupation of the mother? & Merchant \\
\hline & & Farmer \\
\hline & & Government employee \\
\hline 106 & Number of children ever born by the mother & \\
\hline 107 & Number of children alive & 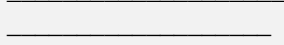 \\
\hline 108 & The age of your most recent child is & 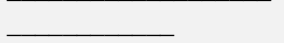 \\
\hline 109 & What is your family monthly income per month? & \\
\hline & & Amhara \\
\hline 110 & Ethnicity & Tigray \\
\hline 111 & Place of birth & Oromo \\
\hline & & Other, specify \\
\hline
\end{tabular}


Section B: Knowledge related questions

\begin{tabular}{|c|c|c|}
\hline S. No. & Questions & Responses \\
\hline \multirow{2}{*}{201} & Have you heard of expanded program of immunization? (If no go to question & Yes \\
\hline & No 203$)$. & No \\
\hline \multirow{5}{*}{202} & \multirow{5}{*}{ If yes for question no. 201 from where did you hear? } & Radio \\
\hline & & Television \\
\hline & & Friends/peers \\
\hline & & School \\
\hline & & Health personnel \\
\hline \multirow{4}{*}{203} & \multirow{4}{*}{ Do you mention the purpose of vaccinating a child? } & To prevent vaccine specific disease \\
\hline & & For treating childhood disease \\
\hline & & Don’t know \\
\hline & & Other, specify \\
\hline \multirow{9}{*}{204} & \multirow{9}{*}{ How many vaccine preventable diseases do you know? } & Measles \\
\hline & & Pneumonia \\
\hline & & Tetanus \\
\hline & & Polio \\
\hline & & Pertussis \\
\hline & & Hepatitis \\
\hline & & Tuberculosis \\
\hline & & Diphtheria \\
\hline & & Homophilesinfluenza \\
\hline \multirow{6}{*}{205} & \multirow{6}{*}{ How many vaccination sessions are needed for a child to be fully protected? } & One \\
\hline & & Two \\
\hline & & Three \\
\hline & & Four \\
\hline & & Five \\
\hline & & Don't know \\
\hline \multirow{4}{*}{206} & \multirow{4}{*}{ Do you tell me the age at which the child begins immunization? } & Just at birth \\
\hline & & after one year \\
\hline & & Six weeks after birth \\
\hline & & I don't know \\
\hline \multirow[t]{2}{*}{207} & \multirow[t]{2}{*}{ At what age the child should complete immunization? } & Greater or equal to one year \\
\hline & & I Don't know \\
\hline \multirow{3}{*}{208} & \multirow{3}{*}{ Do you think vaccination will make your child sick? } & Yes \\
\hline & & No \\
\hline & & Don't know \\
\hline \multirow{2}{*}{209} & \multirow{2}{*}{ Do you bring a sick child for vaccination? } & Yes \\
\hline & & No \\
\hline
\end{tabular}

Section C: Attitude related questions

\begin{tabular}{|c|c|c|}
\hline S No. & Questions & Responses \\
\hline \multirow{3}{*}{301} & \multirow{3}{*}{ I think vaccine that costs too much } & Agree \\
\hline & & Disagree \\
\hline & & Don't know \\
\hline \multirow{3}{*}{302} & \multirow{3}{*}{ I am in need of protection against vaccine preventable infection? } & Agree \\
\hline & & Disagree \\
\hline & & Don't know \\
\hline \multirow{3}{*}{303} & \multirow{3}{*}{ Immunization is important for infants } & Agree \\
\hline & & Disagree \\
\hline & & Don't know \\
\hline \multirow{3}{*}{304} & \multirow{3}{*}{ Vaccination causes complication to infants? } & Agree \\
\hline & & Disagree \\
\hline & & Don't know \\
\hline \multirow{3}{*}{305} & \multirow{3}{*}{ Vaccination will not work / have no use? } & Agree \\
\hline & & Disagree \\
\hline & & Don’t know \\
\hline \multirow{3}{*}{306} & \multirow{3}{*}{ Vaccination is against to my religion / cultures? } & Agree \\
\hline & & Disagree \\
\hline & & Don't know \\
\hline \multirow{2}{*}{307} & \multirow{2}{*}{ I advise other mothers to get their children immunized? } & Agree \\
\hline & & Disagree \\
\hline
\end{tabular}




\begin{tabular}{lll}
\hline S No. & Questions & Responses \\
\hline & & Don't know \\
& & Agree \\
308 & Do you think vaccinators do experiment on infants? & Disagree \\
& & Don't know \\
& & Agree \\
309 & Vaccination side effects are dangerous? & Disagree \\
& & Don't know \\
310 & Immunization is important only for non-serious disease? & Disagree \\
& & Don't know \\
\hline
\end{tabular}

Section D: practice related questions

\begin{tabular}{lll}
\hline S No. & Questions & Responses \\
\hline 401 & Does your child take any vaccination? & Yes \\
402 & Do you have a card where vaccinations are written down? & No \\
& & Yes \\
403 & Does all your child completed vaccination? & No \\
404 & Do you Confirming BCG vaccination By looking the presence of BCG scar & Yes \\
& & I don't know \\
405 & Do you Adhere to immunization schedule & Yes \\
& & No \\
406 & Does the child taking vaccination at correct schedule? & Yes \\
& & No \\
407 & Infant immunization practice always by EPI card? & Yes \\
408 & Have you had Tetanus Toxoid (TT) vaccination during pregnancy? & No \\
& & Yes \\
409 & If yes for question number 409 how many doses have you taken? & No \\
& & Once \\
\hline
\end{tabular}

\section{References}

[1] WHO. Fact sheet $\mathrm{N}^{\circ} 288$ Immunization against diseases of public health importance Geneva 2010 and 2013].

[2] WHO recommended vaccines BCG, Hepatitis B, Polio, DPT, Hib, pneumococcal, rotavirus, measles, rubella, HPV. [Cited 2014 October 4]; Available from World Health Organization: Global elimination of measles. 2009, Geneva.

[3] Ethiopia National Expanded Programme on Immunization; Comprehensive Multi-Year Plan 2016-2020," Addis Ababa: Federal Ministry of Health, Ethiopia, 2015.

[4] FMOH. Policy Guidelines of the National Expanded Program on Immunization in Ethiopia. Addis Ababa; 2013.

[5] UNICEF: Level \& Trends in Child Mortality. The UN InterAgency Group for Child Mortality Estimation. 2014.

[6] WHO, UNICEF: Immunization summary, a statistical reference containing data through 2013.

[7] Federal Democratic Republic of Ethiopia Ministry of Health. Annual Performance Report Of HSDP-III. 2016.

[8] Federal Democratic Republic of Ethiopia Ministry of Health. Health and health related indicators, 2011 G. C.

[9] Ethiopia Health and Nutrition research institute. Ethiopian national immunization coverage: Addis Ababa, 2012.

[10] United States agency for international Development. Essential Service for Health in Ethiopia: Child survival, 2017.

[11] World Health Organization, Regional office for African Expanded program on immunization, 2012.

[12] Anna E. Shurtleff. Attitudes, Beliefs and Behaviors of Parents towards Childhood Immunizations. University of North Texas Health Science Center UNTHSC Scholarly.

[13] Al Madinah, Saudi Arabia Parents' Knowledge, Attitude and Practice towards Childhood Vaccination, 2017.

[14] Dr. A Dut C. Malual MB. B. S University of Juba Prevalence and factor Associated with for immunization in children Attending pediatric outpatient clinic at juba teaching hospital.

[15] Mapatano MA. Immunization-related knowledge, attitudes and practices of mothers in Kinshasa, Democratic Republic of the Congo.

[16] Anjum Fazli, Rohul Jabeen, and Dr. Syed Arshad Hussain Andrabi. Immunization of Children in a Rural Area of North Kashmir, India.

[17] Belachew Etana. Factors Affecting Immunization Status of Children Aged 12.

[18] Months in Ambo Worda, West Shewa Zone of Oromia regional State. 2011.

[19] Birhanu S, Anteneh A, Kibie Y, Jejaw A. Knowledge, attitude and practice of mothers towards immunization of infants in health centres at Addis Ababa, Ethiopia. Am J Health Res. 2016 Feb 16; 4 (1): 6-17. 
[20] Mohammed S, Tamiru D. The burden of diarrheal diseases among children under five years of age in Arba Minch District, southern Ethiopia, and associated risk factors: a crosssectional study. International scholarly research notices, 2014. 